\title{
Halal Tourism: Its Attractiveness to Domestic Tourists Based on Their Religious Perspectives
}

\author{
Ambara Purusottama ${ }^{1 *}$, Gregorius Dimas Hapsoro Prastowo ${ }^{2}$ \\ ${ }^{1}$ School of Business and Economic, Universitas Prasetiya Mulya, Tangerang, Indonesia \\ ${ }^{2}$ Business Venture and Development Institute, School of Business and Economic, Universitas Prasetiya Mulya, \\ Tangerang, Indonesia
}

\begin{abstract}
One of Indonesia's government programs to boost tourism as the basis of Indonesia's economy is Halal tourism. This study aimed at exploring the behavior of domestic Muslim tourists when considering halal tourist destinations. It also looked at Muslim tourists' behavior as they selected and recommended halal tourist destinations and compared the results according to the degree of taqwa in performing their religious rituals. This study used judgmental sampling in the selection of respondents and successfully collected 511 valid questionnaires. The theory of planned behavior (TPB) was used to analyze the study subjects, namely domestic Muslim tourists when they intended to select and recommend halal tourist destinations. It revealed that when domestic Muslim tourists intended to select and recommend halal tourist destinations, they influenced by Behavior Control. Attitude and Subjective norm did not influence the intention to select and recommend halal tourist destinations. Moreover, there was an adverse relationship between Attitude and Subjective Norm in the intention. The result of this study may contribute to the behavior theory and expand the use of TPB in the field of halal tourism study.
\end{abstract}

Keywords: Degree of taqwa, domestic tourists, halal tourist destinations, theory of planned behavior.

\section{INTRODUCTION}

Tourism has become an important activity and has grown rapidly into a global phenomenon and a major industry. In 2007, UNWTO estimated that by 2020, there would be 1.6 billion worldwide tourists spending around US\$ 2 trillion. The reality, however, has exceeded the prediction. Data from UNWTO in 2016 recorded 1.235 billion tourists and the tourism industry contributed $10 \%$ to the GDP, $30 \%$ to the service industry, and $7 \%$ to the export value worldwide [1].

Its growth in the Asia Pacific has had a close link to that of regional tourism. Throughout 2016, the number of international tourists in the region reached 113.23 million with 5 (five) countries responsible for the largest number of tourism visits: Thailand 32.58 million; Malaysia 26.75 million; Singapore 16.40 million; Indonesia 12.02 million, and; Vietnam 1.01 million [2]. Indonesia's financial performance showed that the revenue from the tourism industry ranked the fourth largest under fossil fuel, crude palm oil, and coal. Ministry of Tourism in 2016 projected that the tourism sector would become the highest contributor to the revenue in 2019 with

\footnotetext{
* Correspondence Address:

Ambara Purusottama

Email : ambara.purusottama@pmbs.ac.id

Address : Jl. R.A. Kartini, RT.14/RW.6, Cilandak Barat, South Jakarta, 12430.
}

approximately US\$ 24 billion, exceeding other sectors.

A study conducted by Talib and Johan [3] revealed that people's daily activities, especially the Muslims, were strongly influenced by the faith they held, and this included the choices they made for holidays. The halal label became a way of finding out whether or not a certain choice was in line with Islamic teaching and worth selecting [4].

In other words, the halal label became the determining factor between products that were deemed permissible according to the religious teaching and products that were still deemed questionable, although they met several other criteria of being halal. In buying a product or using a service, an individual also influenced by his/her degree of taqwa. A decision for purchase was strongly influenced by the faith that people held and devote Muslim would strictly adhere to the teaching of the faith when making decisions [5].

In some countries, tourism constitutes the backbone of its economy $[6,7]$. Halal tourism is a breakthrough concept for Indonesia in its effort to increase the number of international tourists visiting the country and to increase the chance of tourism becoming the main contributor to the country's economy. The main market targets for this industry are countries with Muslim populations, Middle Eastern and African countries, and local tourists from Indonesia - a 
country with the largest Muslim population in the world.

Halal tourism is an extension of the halal concept that has become a more and more important consideration for the Muslim community since halal products themselves are still not popular, especially among the community [8]. The term halal, which is synonymous with a certain religion, becomes a challenge to other religions since their religions do not prescribe the same belief $[9,10]$.

The objective of this study is to explore people's perception of halal tourism concept and to evaluate the concept using Lombok Island, Indonesia as the sample since the island set as one of the world's halal tourist destinations. This study used the Theory of Planned Behavior (TPB) to explore the relationship between the behaviors of domestic Muslim tourists and the concept of halal tourism.

This study is a breakthrough study in the field of halal tourist behaviors that used the TPB as its basis to link the halal concept with tourism. To strengthen the result of the study, the researchers used the degree of taqwa as the variable moderator to find out the effect of such variable on the intention of the selection of halal tourist destinations. This study used the crosssectional approach by targeting domestic tourists who possessed some knowledge of halal tourism.

\section{Planned Behavior (TPB)}

Although other theories can be used to study behaviors of individuals or organizations, the theory of planned behavior (TPB) as pioneered by Ajzen in 1980 especially discusses the involvement of participants in the selection of products and services [11]. TPB is used to understand the decision-making process done by individuals and organizations [12]. The main objective of the theory is to show a more comprehensive understanding of an individual's or an organization's behavior.

TPB explains that the desire and behavior of individuals influenced by three main factors: Attitude, Subjective Norm, and Behavior Control. The behavioral belief or attitude is a person's attitude when receiving a positive and negative response to something that he or she feels. This feeling derives from what the person believes to be the consequences of the action. The normative belief or Subjective Norm is a perception or an opinion built by other individuals, which is considered influential to a person's desire. Subjective norm can also mean a social pressure which influences a person's desire. The control belief or Behavior Control is a perception made by an individual in their behavior. It may reflect the person's experience in the past and symbolize anticipation of future obstacles.

TPB has advantages compared to other behavior theories. First, TPB applies to various disciplines. TBP is also able to provide a closer illustration of an individual's or an organization's behavior than other theories. For many researchers, a few elements of TPB provide better values, and the theory itself has been used multiple times to support studies from other disciplines using various approaches. Some studies used TPB to analyze consumer's behavior in purchasing products and services [13-15]. TPB was also specially used to analyze the halal concept to explain the desire and behaviors of consumers of halal products $[16,17]$.

\section{TPB on Tourism}

In the context of tourism, a few scholars have used TPB as the basis of their studies. A tourist destination requires 4 basic attributes, namely attraction, access, amenities/facilities and additional services [18]. TPB also used to evaluate the effectiveness of TPB in predicting the intentions of the visitors in selecting a tourist attraction/destination [19].

From the perspective of transport/access selection, TPB applied to predict the behavior of prospective passengers in selecting Low-Cost Carriers (LCCS) in South East Asia region [20] and accommodation selection [21]. TPB also used to study the desire of the consumers in purchasing food [22]. While others used TPB explained that there was a time-lapse between the intention of traveling and arriving in the destination, which caused a specific difference between planning and realization of choices made by the tourists [23].

The application of TPB seen in the study on the selection of worldwide tourist destinations [24]. The study revealed that the Social Environment and Behavior Control contributed to the selection of worldwide tourist destinations while Attitude only applied to certain destinations. The three factors of TPB contributed positively to the selection of tourist destinations by using Word of Mouth (WOM) as the marketing medium [25]. In this digital era, WOM has become important as it can reach wider consumers. 


\section{TPB and the Selection of Halal Products}

The behavior to purchase halal products has been the source of attraction for researchers, although the scope of such products is still limited to food and drinks. The prior study argued that in selecting halal products, individuals positively influenced by three factors: Attitude, Social Environment, and Behavior Control [22]. The study revealed that Attitude became the dominating factor for predicting Malaysian consumers' selection of halal products, followed by Social Environment, and Behavior Control.

However, social Environment no longer became a consideration in selecting food and drink products [26]. For the Muslims, religious synonymity attached to halal products such as food became the main consideration. A Muslim consumer would try to obtain halal products, and they were willing to make extra efforts to ensure their life was in line with Islamic teaching [27].

Another study on the selection of halal products revealed that Social Environment factor did not affect the selection of halal products [28]. The study also stated that the selection of halal products was mainly influenced by Attitude and Behavior control, consecutively. While other study revealed the opposite by revealing that Social Environment still played a role in the selection of halal products [17]. Other researchers argued that Attitude and Behavior Control more often became the determining factors compared to Social Environment.

\section{RESEARCH HYPOTHESIS AND FRAMEWORK}

The study used TPB as the guideline as it was believed to be able to provide a more comprehensive perspective in the study of human and organizational behavior, see Figure 1 for the detail. Studying behavior is nothing simple since many factors influencing an individual. Therefore, this study was limited to the Intention indicator.

The intention considered representative and much simpler since it has a higher chance of accuracy compared to Behavior. There was not enough evidence to see the difference between Intention and Behavior [29]. Other researchers said that there was a moderate relationship between Intention and Behavior in the decision to purchase products [30].

An attitude is a form of individual response to positive or negative influences an individual is exposed to and will influence the subsequent actions of such individual [12]. In this context, the hypotheses are to find out whether Attitude influences the Intention of people to select halal tourism. Therefore, the hypotheses are:

Ha1: Religiosity moderating the relationship between Attitude and Intention to visiting halal tourist destinations.

Ha2: Religiosity moderating the relationship between Attitude and Intention to recommending halal tourist destinations.

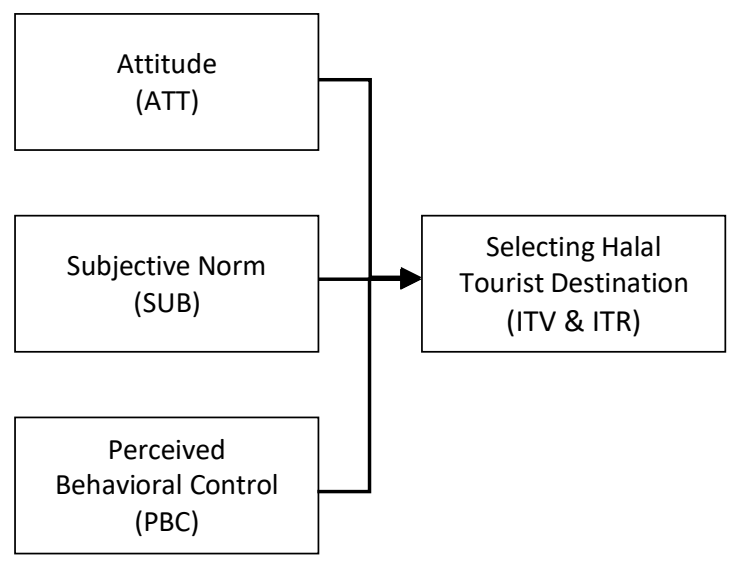

Figure 1. Framework of TPB-Based Study

Subjective Norm is a pressure from the environment on an individual against something that the individual believes in. In this context, the hypotheses are to find out whether social pressure encourages the Intention of an individual to select halal tourist destinations. The hypotheses are:

Ha3: Religiosity moderating the relationship between Subjective Norm and Intention to visiting halal tourist destinations.

Ha4: Religiosity moderating the relationship between Subjective Norm and Intention to recommending halal tourist destinations.

Behavior Control is feelings an individual has when he/she encounter difficulties or easiness in deciding how to behave. It influenced by a locus of control which is an individual's belief on the situation he/she faces and may change at any time depending on the situation. Behavior Control becomes the sole factor that influences an individual in their actions or in making decisions. In this context, the hypotheses are to find out whether Behavior Control influences the Intention of an individual to select halal tourist destinations. The hypotheses are:

Ha5: Religiosity moderating the relationship between Behavior Control and intention to visiting halal tourist destinations. 
Ha6: Religiosity moderating the relationship between Behavior Control and intention to recommending halal tourist destinations.

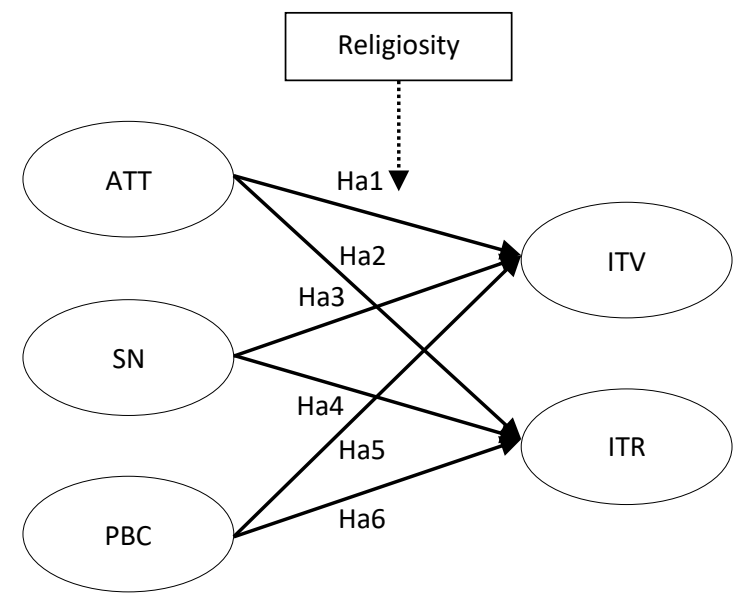

Figure 2. Research Hypothesis

Description: $\mathrm{ATT}=$ Attitude $\mathrm{SN}=$ Subjective Norm $\mathrm{PBC}=$ Perceived Behavioral Control ITV = Intention to Visit ITR = Intention to Recommend

\section{MATERIAL AND METHOD}

Data were collected using a survey method with questionnaires. Individuals with Islamic faith and the ability to reach halal tourist destinations in Lombok Island were selected as respondents using the purposive sampling method. The use of purposive sampling method is to support this study where information obtained from a certain target group [31].

The sample collected was limited to individuals who were able to provide the information needed for the study according to the criterion set. The purposive sampling suiting this study was the judgment sampling whereby the sample collection involved subjects who were most beneficial for the study and in the best positions to provide the information.

The survey used the questionnaire instrument measured by the Likert scale. The Likert scale shows the strength of an agreement or disagreement on a statement. The range of the scale is 1 for Strongly Disagree, 2 for Disagree, 3 for Fairly Disagree, 4 for Neutral, 5 for Fairly Agree, 6 for Agree, and 7 for Strongly Agree. The range 1 - 7 was used to obtain optimum data reliability compared to other ranges in the Likert scale, and this scale was commonly used [32].

Moreover, the researchers also used the context of faith/belief and taqwa and used the degree of taqwa as a moderator variable. The researchers grouped the subjects based on two statements, which were made based on the degree of taqwa or the discipline individuals had in performing their religious rituals, namely Devote Muslim and Cultural Muslim. The statement for Devote Muslim was "As much as I could, I perform all religious rituals prescribed by God on time" while the statement for the Cultural Muslim was "If I have the time, I perform all religious rituals prescribed by God."

The framework of this research became the basis to build research instruments that employ 5 latent variables: Attitude, Social Environment, Behavior Control, Intention to visit, and Intention to recommend. Lombok Island used as the selected halal tourist destinations. To make it easy for the respondents to understand and fill out the questionnaires, the researchers only created three measurement variables from each latent variable.

The statement for Attitude variable was based on the knowledge and/or experience the respondents had. The Subjective Norm variable consisted of norms which should be done by the individual and was more descriptive. Behavior Control referred to the individual's independence and capacity.

The Intention referred to the will that the decision-maker desired. The researchers adjusted the variables to fit the halal tourism context, which was the objective of the study. Details of the instruments seen in Table 1.

\section{RESULTS \\ Profiles of Respondents}

The data collected from 511 respondents, all are urban residents (Table 2). Based on age, respondents with the age of $<=30$ are the most 155 respondents $(30.3 \%)$, > $=40$ and $<50$ with $135(26.4 \%),>30$ and < 40 with $134(26.2 \%)$, and $>=50$ with 87 respondents (17.0\%). Based on their educational background, diploma/ undergraduate was the largest with 381 respondents $(74.6 \%)$, followed by graduate and high school with 105 (20.5\%) and 25 (4.9\%) consecutively. When grouped based on their monthly spending, respondents with 5-10 million and $>10$ million were the most with 178 (34.8\%) and 177 (34.6\%) consecutively.

Based on the variable moderator namely the degree of taqwa, 333 respondents (65.2\%) felt that they performed all religious rituals on time (Devote Muslim) while the rest, which was 178 (34.8\%), felt that they would only perform the religious rituals if they had the time (Cultural Muslim). 
Table 1. Research Instrument [33-35]

\begin{tabular}{clc}
\hline No & \multicolumn{1}{c}{ Statements } & Code \\
\hline 1 & Based on the information I have had, halal tourist destinations are safe destinations. & att_1 \\
2 & Visiting halal tourist destinations is a pleasant experience. & att_2 \\
3 & Halal tourist destinations are the best place for self-actualization. & att_3 \\
\hline 4 & I have the fund, time and opportunity to go on a holiday. & pbc_1 \\
5 & I am the decision-maker for visiting halal tourist destinations & pbc_2 \\
6 & Tough difficult, I prioritize going to halal tourist destinations. & pbc_3 \\
\hline 7 & My close friends influence my decision in selecting halal tourist destinations. & sub_1 \\
8 & My close relatives influence my decision in selecting halal tourist destinations. & sub_2 \\
9 & My role model influences my decision in selecting halal tourist destinations. & sub_3 \\
\hline 10 & I intend to purchase a packaged tour to a halal destination. & itv_1 \\
11 & I intend to visit a halal tourist destination soon. & itv_2 \\
12 & I am more interested in purchasing a packaged tour to a halal destination than to other destinations. & itv_3 \\
\hline 13 & If asked, I encourage people to select halal tourist destinations. & itr_1 \\
14 & I will always recommend halal tourist destinations to people. & itr_2 \\
15 & When the opportunity arises, I will immediately recommend halal tourist destinations to people close to me. & itr_3 \\
\hline
\end{tabular}

Table 2. Profile of Respondents

\begin{tabular}{lllr}
\hline Profile & Range & Frequency & Percent \\
\hline \multirow{4}{*}{ Age } & $<=30$ & 155 & $30.3 \%$ \\
& $>30$ and $<40$ & 134 & $26.2 \%$ \\
& $>=40$ and $<50$ & 135 & $26.4 \%$ \\
& $>=50$ & 87 & $17.0 \%$ \\
\hline \multirow{2}{*}{ Educational } & High School & 25 & $4.9 \%$ \\
Background & Diploma/Under & & \\
& Graduate & 381 & $74.6 \%$ \\
& $>=$ Graduate & 105 & $20.5 \%$ \\
\hline \multirow{2}{*}{ Monthly } & $3-5$ million & 156 & $30.5 \%$ \\
Spending & 5-10 million & 178 & $34.8 \%$ \\
& $>10$ million & 177 & $34.6 \%$ \\
\hline Religiosity & Cultural Muslim & 178 & $34.8 \%$ \\
Approach & Devote Muslim & 333 & $65.2 \%$ \\
\hline
\end{tabular}

\section{Validity and Reliability}

The result of data testing showed that the data obtained were valid and reliable (Table 3 and Fig. 3). The values reflected in the $C R$ and AVE were according to the requirement with $C R>$ 0.6 and AVE > 0.5. The CR values on the latent variable showed that they fulfilled the requirement with ATT (0.883), SUB (0.949), PBC (0.815), ITV (0.904), and ITR (0.975). It shows that the data were reliable. The AVE values also fulfilled the requirement with ATT (0.720), SUB (0.845), PBC (0.737), ITV (0.739), and ITR (0.882) which shows that data collected were valid.

\section{Discriminant Validity}

The exogeny variable data have fulfilled the requirement of discriminant validity (Table 4). The discriminant validity may occur when two different variables do not have a strong correlation or are smaller than the correlation in the same variables. The values of ATT (0.848), SUB (0.919), and PBC (0.859) are bigger than the correlation of different variables with $A T T$-> SUB (0.442), ATT $\rightarrow$ PBC (0.817), and SUB $\rightarrow$ PBC
(0.777). It concluded that the variables tested fulfilled the requirement of discriminant validity.

Table 3. Data Validity and Reliability

\begin{tabular}{lccccc}
\hline & ATT & SUB & PBC & ITV & ITR \\
\hline $\begin{array}{l}\text { Standard } \\
\text { Loading }\end{array}$ & 2.013 & 2.178 & 1.277 & 2.147 & 2.589 \\
\hline $\begin{array}{l}\text { Measurement } \\
\text { of Error }\end{array}$ & 0.540 & 0.294 & 0.311 & 0.547 & 0.301 \\
\hline CR & 0.883 & 0.949 & 0.815 & 0.904 & 0.975 \\
\hline AVE & 0.720 & 0.845 & 0.737 & 0.739 & 0.882 \\
\hline Decision & $\mathrm{S}$ & $\mathrm{S}$ & $\mathrm{S}$ & $\mathrm{S}$ & $\mathrm{S}$ \\
\hline
\end{tabular}

Notes: ATT $=$ Attitude, SUB $=$ Subjective Norm, PBC= Perceived Behavioral Control, ITV=Intention to Visit, ITR= Intention to Recommend

(S) Supported, if CR $>0.6$ and AVE $>0.5$

(NS) Not Supported, if CR $<=0.6$ and AVE $<=0.5$

Table 4. Discriminant Validity

\begin{tabular}{lcccc}
\hline & ATT & SUB & PBC & Decision \\
\hline ATT & 0.848 & 0.442 & 0.817 & S \\
\hline SUB & 0.442 & 0.919 & 0.777 & S \\
\hline PBC & 0.817 & 0.777 & 0.859 & S
\end{tabular}

Notes: ATT $=$ Attitude, SUB $=$ Subjective Norm, $\mathrm{PBC}=$ Perceived Behavioral Control. (S) Supported if SQRT AVE > correlation with other variables; (NS) Not Supported if SQRT AVE <= correlation with other variables

\section{Goodness-of-fit}

Table 5 explains that the model created was suitable since it fulfilled the required values. The results were a few indicators of goodness-of-fit that were used according to the values required. The CMIN/df produced the value of 1.836 or lower than the value required which was $<2$ while the values of CFI, TLI, and RMSEA produced the required values with CFI with $0.933>0.90$, TLI with $0.914>0.92$, RMSEA with $0.075<0.08$. On the other side, the GFI indicator was not able to fulfill the value required with 0.880 or smaller than the value required. However, the value of 


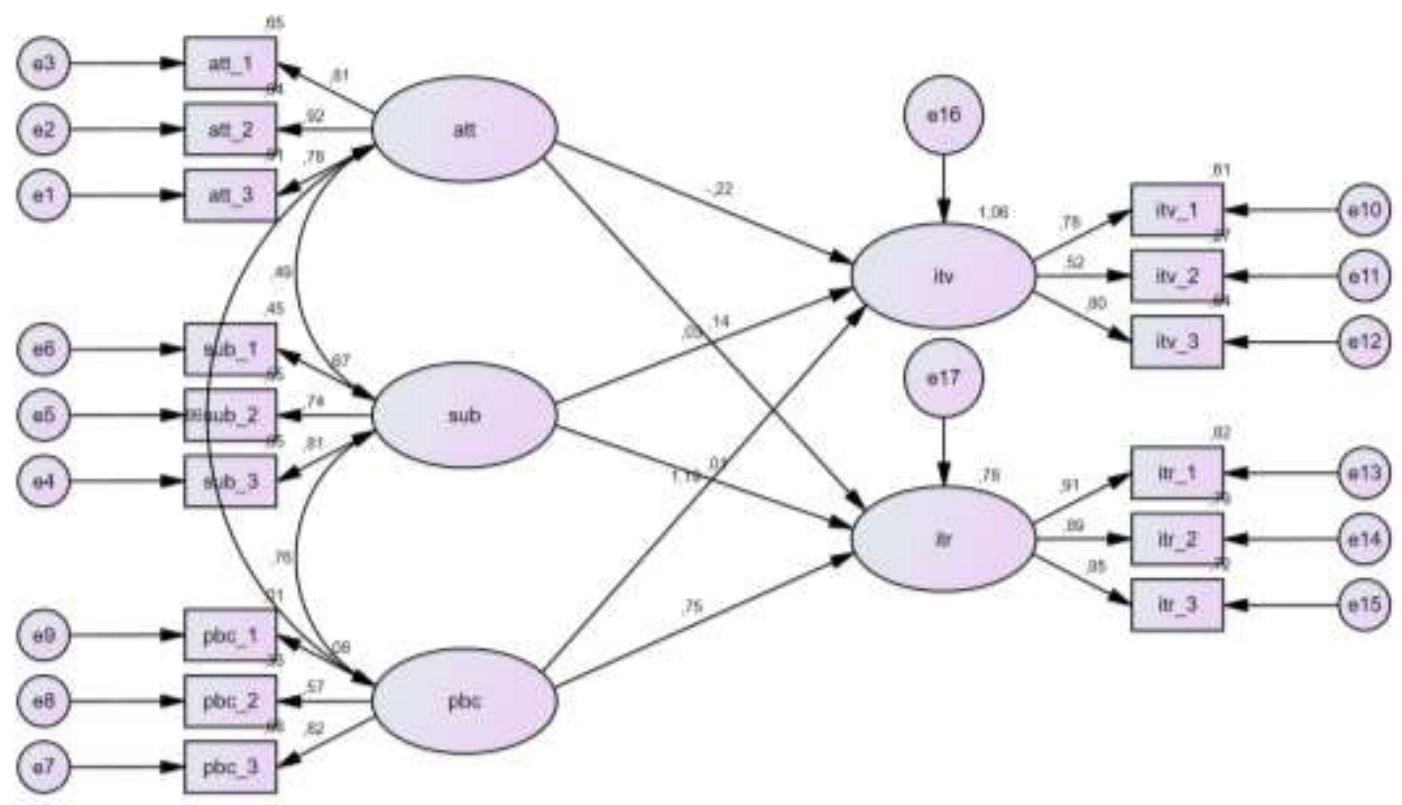

Figure 3. Data Testing Result

Description: $\mathrm{ATT}=$ Attitude, $\mathrm{SUB}=$ Subjective Norm, $\mathrm{PBC}=$ Perceived Behavioral Control, ITV=Intention to Visit, ITR= Intention to Recommend.

Table 5. The Result of Goodness of Fit Testing

\begin{tabular}{|c|c|c|c|}
\hline $\begin{array}{l}\text { Goodness of } \\
\text { Fit } \\
\text { Measurement }\end{array}$ & $\begin{array}{l}\text { Match } \\
\text { Level } \\
\text { Target }\end{array}$ & $\begin{array}{l}\text { Estimation } \\
\text { Result }\end{array}$ & $\begin{array}{l}\text { Fit } \\
\text { Measurement }\end{array}$ \\
\hline \multirow[b]{2}{*}{$x^{2}$} & \multirow[b]{2}{*}{$\leq 2-5$} & $x^{2}=48.752$ & \multirow[b]{2}{*}{ Good Fit } \\
\hline & & $\begin{array}{l}\mathrm{X}^{2} / \mathrm{df}= \\
0.836\end{array}$ & \\
\hline CFI & $>.92$ & 0.933 & Good Fit \\
\hline TLI & $>.92$ & 0.914 & Good Fit \\
\hline RMSEA & $\begin{array}{l}\text { Values } \\
<.08\end{array}$ & 0.075 & Good Fit \\
\hline GFI & $>.90$ & 0.880 & Marginal Fit \\
\hline
\end{tabular}

\section{Hypothesis Testing}

The relationships among the variables were only all consistent (Table 6). The relationship between ATT variable and its endogeny variables - ITV and ITR - produced two different results. While the ATT and ITV produced a negative result $(-0.246)$, ATT and ITR produced a positive result (0.029). However, the relationships between SUB variable and ITV and ITR variable were consistent with both variables producing negative results.

The relationship between PBC variable and ITV and ITR variable was also consistent with both variables producing positive results. From all relationships among variables, only the relationship between PBC variable and ITV and ITR variable was able to fulfill the significance criterion. Therefore, it concluded that only the relationship between PBC and its endogeny variables was positive and significant.

\section{General Hypothesis}

Not all the relationships among the variables developed were able to fulfill the requirement of being a significant relationship (Table 6). The result of the testing shows that only the relationship between the $\mathrm{PBC}$ variable and its endogeny variables was able to fulfill the criterion set. The relationship between PBC variable and ITV and ITR variable was able to gain the P-value of 0.000 , which suits the minimum criterion of significance level $99 \%$ with the Pvalue $<0.001$.

Meanwhile, this result was in contrast to the relationship between other exogeny variables: ATT and SUB. The relationship between ATT and SUB variable and their endogeny variables - ITV and ITR - was not able to produce the value set. Each was only able to produce the $P$ value between ATT and ITV and ITR variable of 0.226 and 0.839 consecutively. Also, the relationship between SUB variable and ITV and ITR variable was 0.873 and 0.454 consecutively. Therefore, it can be concluded that $\mathrm{Ha} 1, \mathrm{Ha} 2, \mathrm{Ha} 3$, and $\mathrm{Ha} 4$ hypotheses are rejected while $\mathrm{Ha} 5$ and $\mathrm{Ha} 6$ hypotheses are accepted. 
Table 6. General Hypothesis Test Result

\begin{tabular}{clllcccc}
\hline Hypothesis & \multicolumn{2}{c}{ Relationship } & Estimate (U) & Estimate (S) & P-Value & Decision \\
\hline Ha1 & ATT & $--->$ & ITV & -0.266 & -0.246 & 0.226 & NS \\
Ha2 & ATT & $--->$ & ITR & 0.031 & 0.029 & 0.839 & NS \\
\hline Ha3 & SUB & $--->$ & ITV & -0.022 & -0.023 & 0.873 & NS \\
Ha4 & SUB & $--->$ & ITR & -0.079 & -0.080 & 0.454 & NS \\
\hline Ha5 & PBC & $--->$ & ITV & 1.126 & 1.237 & 0.000 & $S^{* * *}$ \\
Ha6 & PBC & $--->$ & ITR & 0.849 & 0.932 & 0.000 & $S^{* * *}$ \\
\hline
\end{tabular}

Notes: (S) Supported; (NS) Not Supported

${ }^{*}$ significant at $0.05 ;{ }^{* *}$ significant at $0.01 ;{ }^{* * *}$ significant at 0.001

Table 7. Religiosity-Based Hypothesis Test

\begin{tabular}{|c|c|c|c|c|c|c|c|c|c|}
\hline \multirow[b]{2}{*}{ Hypothesis } & \multirow{2}{*}{\multicolumn{2}{|c|}{ Relationship }} & & \multicolumn{2}{|c|}{ Estimate (S) } & \multicolumn{2}{|c|}{ P-Value } & \multicolumn{2}{|c|}{ Decision } \\
\hline & & & & $\begin{array}{l}\text { Cultural } \\
\text { Muslim }\end{array}$ & $\begin{array}{l}\text { Devout } \\
\text { Muslim }\end{array}$ & $\begin{array}{l}\text { Cultural } \\
\text { Muslim }\end{array}$ & $\begin{array}{l}\text { Devout } \\
\text { Muslim }\end{array}$ & $\begin{array}{l}\text { Cultural } \\
\text { Muslim }\end{array}$ & $\begin{array}{l}\text { Devout } \\
\text { Muslim }\end{array}$ \\
\hline $\mathrm{Ha} 1$ & ATT & $-->$ & ITV & -0.231 & $-0,220$ & 0,451 & 0,433 & NS & NS \\
\hline $\mathrm{Ha} 2$ & ATT & $--->$ & ITR & -0.267 & 0,144 & 0,439 & 0,373 & NS & NS \\
\hline $\mathrm{Ha} 3$ & SUB & $--->$ & ITV & -0.189 & 0,030 & 0,466 & 0,885 & NS & NS \\
\hline $\mathrm{Ha} 4$ & SUB & $--->$ & ITR & -0.423 & 0,010 & 0,167 & 0,939 & NS & NS \\
\hline $\mathrm{Ha} 5$ & PBC & $--->$ & ITV & 1,282 & 1,185 & 0,005 & 0,005 & $\mathrm{~S}^{* *}$ & $\mathrm{~S}^{* *}$ \\
\hline $\mathrm{Ha} 6$ & PBC & $--->$ & ITR & 1,383 & 0,752 & 0,008 & 0,002 & $\mathrm{~S}^{* *}$ & $\mathrm{~S}^{* *}$ \\
\hline
\end{tabular}

Notes: (S) Supported; (NS) Not Supported

${ }^{*}$ significant at 0,$05 ;{ }^{* *}$ significant at 0,$01 ;{ }^{* * *}$ significant at 0,001

\section{Religiosity-Based Hypothesis}

Table 7 shows that the hypotheses based on the degree of taqwa had the same results. In the two degrees of taqwa groups, only the relationship between $\mathrm{PBC}$ and its endogeny variables - ITV and ITR - was able to produce the required $P$ values which were 0.005 and 0.008 for the Cultural Muslim group and 0.005 and 0.002 for the Devote Muslim group. Other relationships did not produce a significant relationship.

The ATT and SUB variables and their endogeny variables were not able to produce the required $\mathrm{P}$ values. For the Cultural Muslim group, the relationships between ATT and SUB and their endogeny variables were ATT -> ITV (0.451), ATT $>$ ITR (0.439), SUB $\rightarrow$ ITV (0.466), and SUB $\rightarrow$ ITR (0.167) while for the Devote Muslim group, the $P$ values for ATT and SUB and their endogeny variables were ATT $\rightarrow>$ ITV (0.433), ATT $\rightarrow>$ ITR (0.373), SUB $\rightarrow>$ ITV (0.885), and SUB $\rightarrow>$ ITR (0.939). Therefore, it can be concluded that the hypotheses based on the degree of taqwa were the same as the general hypotheses: $\mathrm{Ha} 1, \mathrm{Ha} 2$, $\mathrm{Ha} 3$, and $\mathrm{Ha} 4$ are rejected while $\mathrm{Ha} 5$ and $\mathrm{Ha} 6$ are accepted.

The strength of the relationship among the variables during testing based on the degree of taqwa produced varied results. For the Opportunist group, the relationship between the ATT variable and ITV and ITR variable was inconsistent. ATT and ITV variable produced a negative coefficient $(-0.220)$ while ATT and ITR variable produced a positive coefficient (0.144). Also, SUB and ITV and ITR variable produced a positive coefficient with 0.030 and 0.010 consecutively. The same went for PBC and its endogeny variables with positive coefficients for PBC and ITV with the coefficient of 1.185 and ITR with the coefficient of 0.752 .

In the Devout Muslim group, the relationship between ATT variable and ITV and ITR variable produced negative coefficients with -0.231 and 0.267 , respectively. The relationship between SUB variable and ITV and ITR variable also produced negative coefficients with -0.189 and 0.423 consecutively. The relationship between PBC variable and ITV dan ITR variable, however, produced positive coefficients with 1.282 and 1.383.

Based on the result of the hypothesis testing, only the relationship between PBC variable and ITV and ITR variable is significant from the two groups divided based on their degree of taqwa. Therefore, although all relationships among the variables have coefficient values, only the relationship between PBC and its endogeny variables can be considered as an influential factor. The relationship between PBC and ITV and ITR in both degree of taqwa groups is positive and significant. 


\section{DISCUSSION}

Whilst the intentions of individuals selecting certain products or services are generally believed to be influenced by three elements, namely: attitudes, subjective norms, and behavioral control [21], this study reveals that the intentions to visit and recommend halal tourist destinations in Indonesia are influenced solely by behavioral control. The insight contrasts with the commonly held view that, as some previous studies confirmed $[16,26]$, the intention to select halal products dominated by subjective attitudes and norms.

The gap exists due to the narrowly held perception of halal as something attached to consumables, such as food, that affect individuals directly. As such, the concept of halal in broader contexts, for instance, as a tourist destination, has yet to become a mainstream thing to consider by the society.

A similar situation holds for subjective norms [25]. These factors do not emphasize to the intentions of choosing and recommending halal tourist destinations. Moreover, most people in the immediate surrounding also view the halal concept in the context of consumables that affect them directly. It is this view that affects one's interest in halal tourist destinations. Furthermore, to most people in the community, halal tourism is not something to consider when choosing and recommending a halal tourist destination.

Behavioral control is the only variable that places emphasis on those decisions [21,26,27]. For individuals, the confidence in executing the selection of halal tourist destinations is actually not difficult. Even if it is, individuals tend to be able to convert the difficulty--in accessing halal tourist destinations--into an amenity. What comes out of this conversion is a good starting point for future development of halal tourist destinations.

The finding of this study is authentic in revealing that attitudes and subjective norms tend to have a reverse relationship, especially for the Cultural Muslim group. This finding differs from that of previous studies that have invariably reveal positive relationships $[16,25,26]$. Further investigation of information on the Cultural Muslim respondents discloses that there is quite a wide difference between the halal concept as understood by the community and the real halal concept [7]. Halal tourist destination, as a concept, is not considered as a need but rather as something unnecessary and, therefore, tends to be avoided. The narrow understanding of halal to consumables with direct effects on individuals has become a challenge for the expansion of halal as a concept, especially for use as tourist destinations.

This research identifies some gaps existing between tourists and halal tourism organizers. On the demand side, there is a need for continuous education so that the concept of halal tourism can be received and captured positively by all levels of Indonesian society, who are very diverse in culture, ethnicity, race, religion, and group within the archipelago.

Next, there is a need for improved implementation of halal tourism that refers to the halal tourism foundation in terms of policy/legal standardization and availability. Finally, there is a need for collaboration among stakeholders that are better known as the Pentahelix, namely: institutions, the media, associations, and academics.

\section{CONCLUSION AND IMPLICATION}

Behavior Control becomes a single factor in TPB that has a close relationship with the selection of halal tourist destinations. Domestic tourists did not consider the selection of halal tourist destination as something difficult to do. Attitude and Subjective Norm not only did not influence the selection of halal tourist destinations but also gave an adverse effect. When seen from the perspective of piousness, there was very little difference in the result between Devote Muslim and Cultural Muslim.

The only difference is that Attitudes and Subjective Norms of the Devout Follower aligned with the selection of halal tourist destinations. Meanwhile, Attitude and Subjective Norm of the Cultural Muslim tended to contrast with the selection of halal tourist destinations.

This study gives a new understanding of the behavior theory, especially in the context of halal tourism. This study also expands the use of TPB theory in other disciplines. The result of the study revealed an adverse relationship among the variables, Attitude, and Subjective Norms against the selection of halal tourist destinations and inconsistency between the individual perception and the halal concept of tourism.

Further studies are needed to find out more about the inconsistency, especially in the context of domestic Muslim tourists. The government as the maker of the halal tourism program needs to explore further the inconsistency revealed in this study so that the halal tourism concept does not 
only concern trust in the provision of halal food and drinks for tourists, but also that of their comfort and safety, particularly in an equal level of trust.

\section{ACKNOWLEDGEMENT}

This research was fully supported by Universitas Prasetiya Mulya. We thank our colleague, Dr. Eka Ardianto, who provide insight and expertise that greatly assisted the research.

\section{REFERENCES}

[1] UNWTO. 2017. UNWTO tourism highlights. United Nation World Tourism Organization (UNWTO). Madrid.

[2] Ministry of Tourism. 2016. Laporan akuntabilitas kinerja Kementerian Pariwisata. Ministry of Tourism, Republic of Indonesia. Jakarta.

[3] Talib and Johan. 2012. Issues in halal packaging. International Business and Management 5(2), 94-98.

[4] Sukesti, F. and M. Budiman. 2014. The influence halal label and personal religiousity on purchase decision on food products in indonesia. International Journal of Business, Economics and Law 4(1), 150153.

[5] Siala, H. 2013. Religious influences on consumers' high-involvement purchasing decisions. Journal of Services Marketing 27(7), 579-589.

[6] Rahman, M. K. 2014. Motivating factors of islamic tourist's destination loyalty: an empirical investigation in malaysia. Journal of Tourism and Hospitality Management 2(1), 63-77.

[7] Khan, A. H., A. Haque, and M. S. Rahman. 2013. What makes tourists satisfied? an empirical Study on malaysian islamic tourist destination. Middle-East Journal of Scientific Research 14(12), 1631-1637.

[8] Battour, M. and M. N. Ismail. 2016. Halal tourism: concepts, practices, challenges, and future. Tourism Management Perspectives 19(Part B), 150-154.

[9] Yousaf, S. and M. S. Malik. 2013. Evaluating the influences of religiosity and product involvement level on the consumers. Journal of Islamic Marketing 4(2), 163-186.

[10] Essoo, N. and S. Dibb. 2004. Religious influences on shopping behaviour: an exploratory study. Journal of Marketing Management 20(7-8), 683-712.

[11] Ajzen, I. 2015. Consumer attitudes and behavior: the theory of planned behavior applied to consumption decisions. Rivista di Economia Agraria LXX(2), 121-138.

[12] Ajzen, I. 2012. The theory of planned behavior. In: Handbook of Theories of Social Psychology Vol. 1. UK: Sage. 438-459.

[13] Vabo, M. and H. Hansen. 2016. Purchase intentions for domestic food: a moderated TPB-explanation. British Food Journal 118(10), 2372-2387.

[14] Irianto, H. 2015. Consumers' attitude and intention towards organic food purchase: an extension of Theory of Planned Behavior in gender perspective. International Journal of Management, Economics and Social Sciences 4(1), 17-31.

[15] Wang, Y. 2014. Consumers' purchase intentions of shoes: theory of planned behavior and desired attributes. International Journal of Marketing Studies: Canadian Center of Science and Education 6(4), 50-58.

[16] Haro, A. 2015. Understanding TPB model, availability, and information on consumer purchase intention for halal food. International Journal of Business and Commerce 5(8), 47-56.

[17] Khalek, A. A. and S. H. S. Ismail. 2015. Why are we eating halal - using the theory of planned behavior in predicting halal food consumption among generation $y$ in malaysia. International Journal of Social Science and Humanity 5(7), 608-612.

[18] Zabkar, V., M. M. Brencic, and T. Dmitrovic. 2010. Modelling perceived quality, visitor satisfaction and behavioural intentions at the destination level. Tourism Management 31(4), 537-546.

[19] Wang, S. and Y. Y. Fu. 2015. Application of planned behavior and place Image to visit intentions: a casino gaming context. Advances in Hospitality and Leisure 11, 6787.

[20] Buaphiban, T. and D. Truong. 2017. Evaluation of passengers' buying behaviors toward low cost carriers in Souteast Asia. Journal of Air Transport Management 59, 124-133.

[21] Verma, V. K. and B. Chandra. 2018. An application of theory of planned behavior to predict young Indian consumers' green hotel visit intention. Journal of Cleaner Production 172, 1152-1162.

[22] Alam, S. S. and N. M. Sayuti. 2011. Applying the Theory of Planned Behavior (TPB) in 
halal food purchasing. International Journal of Commerce and Management 21(1), 8-20.

[23] Yuzhanin, S. and D. Fisher. 2016. The efficacy of the theory of planned behavior for predicting intention to choose a travel destination: a review. Tourism Review 71(2), 135-147.

[24] Quintal, V. A., J. A. Lee, and G. N. Soutar. 2010. Risk, uncertainty and the theory of planned behavior: A tourism example. Tourism Management 31(6), 797-805.

[25] Jalilvand, M. R. and N. Samiei. 2012. The impact of electronic word a tourism destination choice: testing the theory of planned behavior. Internet Research: Electronic Networking Applications and Policy 22(5), 591-612.

[26] Bonne, K., I. Vermeir, F. Bergeaud-Blackler, and W. Verbeke. 2007. Determinants of halal meat consumption in France. British Food Journal 109(5), 367-386.

[27] Bonne, K. and W. Verbeke. 2006. Muslim consume's attitudes towards meat consumption in Belgium: Insights from a means-end chain approach. Anthropology of Food 5, 1-24.

[28] Khalek, A. A. 2014. Young consumers' attitude towards halal food outlets and JAKIM's halal certification in malaysia. Procedia - Social and Behavioral Sciences 121, 26-34.

[29] Hassan, L. M., E. Shiu, and D. Shaw. 2016. Who says there is an intention-behaviour gap? assessing the empirical evidence of an intention-behaviour gap in ethical consumption. Journal of Business Ethics 136(2), 219-236.

[30] Grimmer, M. and M. P. Miles, 2016. With the best of intentions: a large sample test of the intention-behaviour gap in proenvironmental consumer behaviour. Intenational Journal of Consumer Studies 41(1), 2-10.

[31] Sekaran, U. 2013. Research Methods for Business $6^{\text {th }}$ Ed. John Wiley \& Sons. New York.

[32] Joshi, A., S. Kale, S. Chandel, and D. K. Pal. 2015. Likert scale: explored and explained. British Journal of Applied Science \& Technology 7(4), 396-403.

[33] Autio, E., R. H. Keeley, M. Klofsten, G.G. C. Parker, and M. Hay. 2001. Entrepreneurial intent among students in Scandinavia and in the USA. Enterprise and Innovation Management Studies 2(2), 145-160.
[34] Ajzen, I. 2006. Constructing a theory of planned behavior questionnaire, s.l.: ResearchGate.

[35] Oluka, O. C., S. Nie, and Y. Sun. 2014. Quality assessment of TPB-based questionnaires: a systematic review. PLOS ONE, 9(4).

[36] Sharma, S., S. Mukherjee, A. Kumar, and W. Dillon. 2005. A simulation study to investigate the use of cutoff values. Journal of Business Research 58(1), 935-943. 